\title{
PENINGKATAN EKONOMI MASYARAKAT MELALUI INTENSIFIKASI BUDIDAYA AYAM PEDAGING DESA HAUR GADING KABUPATEN HULU SUNGAI TENGAH
}

\author{
Danang Biyatmoko ${ }^{1}$ dan Tintin Rostini ${ }^{2}$ \\ ${ }^{1}$ Fakultas Pertanian, Universitas Lambung Mangkurat \\ ${ }^{2}$ Fakultas Pertanian, Universitas Islam Kalimantan \\ E-mail : danangbiyatmoko@ulm.ac.id
}

\begin{abstract}
ABSTRAK
Program yang diajukan adalah pemberdayaan ekonomi masyarakat di kawasan lahan gambut, melalui usaha intensifikasi budidaya ayam pedaging di Desa Haur Gading Kecamatan Batang Alai Kabupaten Hulu Sungai Tengah Kalimantan Selatan. Kegiatan ini bertujuan untuk membantu masyarakat agar mampu melakukan budidaya ayam pedaging dengan persyaratan teknis produksi ayam yang baik, sehingga memberikan nilai ekonomis yang lebih tinggi dan selanjutnya akan mensejahterakan masyarakat setempat. Usaha ayam ras pedaging merupakan salah satu jenis usaha yang sangat potensial dikembangkan. Hal ini tidak terlepas dari berbagai keunggulan yang dimilikinya antara lain masa produksi yang relatif pendek kurang lebih 32-35 hari, produktivitasnya tinggi, harga yang relative murah, dan permintaan yang semakin meningkat. Melalui program Badan Restorasi Gambut tahun, dilakukan upaya revitalisasi ekonomi masyarakat gambut di Desa Haur Gading dengan pelatihan dan pendampingan usaha intensifikasi budidaya ayam pedaging. Kegiatan pelatihan diawali dengan sosialisasi kegiatan, penandatanganan Padiatapa, pelatihan teknis perkandangan, pelatihan teknis bibit ayam pedaging, kegiatan budidaya pemeliharaan ayam pedaging selama 31 hari (panen), pendampingan teknis vaksinasi dan pendampingan pemasaran. Peserta program sebanyak 25 orang. Paket program yang diberikan adalah berupa kandang 1 unit ukuran 7 x 17 m, bibit doc ayam 10 boks atau 1000 ekor, pakan 70 sak atau $3500 \mathrm{~kg}$ (pakan starter dan finisher), peralatan pakan dan peralatan minum serta pemanas otomatis (gas solek) serta vaksin dan obat-obatan. Juga dilakukan pendampingan selama budidaya pemeliharaan ayam pedaging yaitu pendampingan teknis budidaya, teknis vaksinasi dan pendampingan pemasaran Respons peserta selama kegiatan dan perangkat desa sangat posistif dan semangat diberikan pelatihan dan permodalan dalam bentuk kandang, bibit, pakan dan vaksin. Monev dan pendampingan terhadap mereka tetap dilakukan hingga semua kegiatan yang dilakukan peserta (kelompok) dapat berhasil mengembangkan kegiatan budidaya ayam pedaging dan dapat melaksanakan kegiatan secara mandiri setelah kegiatan berakhir.
\end{abstract}

Kata kunci : ayam pedaging, ekonomi, , haur gading, masyarakat, revitalisasi

\section{PENDAHULUAN}

Usaha ayam ras pedaging merupakan salah satu jenis usaha yang sangat potensial dikembangkan. Hal ini tidak terlepas dari berbagai keunggulan yang dimilikinya antara lain masa produksi yang relative pendek kurang lebih 32-35 hari, produktivitasnya tinggi, harga yang relative murah, dan permintaan yang semakin meningkat. 
Beberapa faktor pendukung usaha budidaya ayam ras pedaging sebenarnya masih dapat terus dikembangkan, antara lain karena permintaan domestik terhadap ayam ras pedaging masih sangat besar. Kecenderungan ini dapat dihubungkan dengan pertumbuhan permintaan terhadap daging ayam ras yang rata-rata besarnya mencapai $7 \%$ per tahun. Angka kebutuhan nasional terhadap daging ayam ras sebesar 3,3 kg per kapita per tahun. Pertambahan permintaan terjadi karena kenaikan pendapatan perkapita, pertambahan penduduk dan peningkatan kesadaran gizi sebagai akibat berhasilnya program penyuluhan gizi ( Rostini dan Biyatmoko, 2020). Peningkatan permintaan juga terjadi sewaktu-waktu disebabkan karena lonjakan permintaan terjadi pada hari-hari besar (lebaran, natal, tahun baru) maupun pada akhirakhir bulan.

Berdasarkan Data Statistik Perkebunan dan Peternakan KalSel (2019) populasi ayam ras pedaging di Kabupaten HST tahun 2019 yaitu 1.673 .462 ekor atau setara $1.942 .537 \mathrm{~kg}$ daging .Jumlah populasi ayam yang besar ini mampu menyerap tenaga kerja yang bekerja pada peternakan ayam ras pedaging sebanyak 20 ribu lebih. Fakta membuktikan dari tahun ke tahun kebutuhan masyarakat terhadap daging broiler terus meningkat. Seiring dengan meningkatnya minat masyarakat untuk mengkonsumsi daging broiler, terjadi juga peningkatan terhadap usaha peternakan ayam broiler. Ayam ras pedaging dapat dikatakan menjadi salah satu usaha kecil yang memiliki potensi untuk dikembangkan.

Hal yang perlu diperhatikan oleh peternak atau calon peternak, agar usahanya dapat berkesinambungan, diantaranya adalah : 1). Kandang yang memenuhi syarat- syarat teknis dan kesehatan ternak, 2). Peralatan kandang yang vital seperti tempat pakan (feeder), tempat minuman (waterer), pemanas, seng pelindung anak ayam (chick guard), layar/tirai penutup kandang dan alat semprot desinfektan (sprayer) harus tersedia dalam jumlah yang cukup. 3). Anak ayam umur sehari (DOC) yang baik mempunyai ciri-ciri : bulu kering dan bersih, berat tidak dibawah standar (minimal 39 gr/ekor), lincah, tidak mempunyai cacat tubuh dan tidak menunjukkan adanya penyakit-penyakit tertentu seperti ompalitis, berak kapur ataupun pullorum yang dapat dilihat dari adanya kotoran berwarna putih yang melekat pada dubur. 4). Pakan 
yang baik adalah yang cukup mengandung zat-zat makanan yang dibutuhkan oleh ayam (protein, lemak, abu, serat kasar, energi, vitamin dan asam-asam amino). 5) Kesehatan ternak, meliputi antibiotika, vaksin dan vitamin yang dibutuhkan untuk membantu mempertahankan kesehatan ayam, ataupun mengobati ayam bila terserang penyakit.

Baik sistem kemitraan maupun sistem mandiri teknik pemberian pakan harus benar-benar diperhatikan. Bagi anda yang memelihara ayam broiler dengan sistem kemitraan, mungkin metode pemberian pakan pernah diajarkan oleh technical service dari perusahaan inti, namun bagi anda yang membudidayakan ayam broiler secara mandiri tentu saja harus menerapkan metode sendiri secara otodidak atau membaca buku-buku praktis tentang tatacara ternak ayam pedaging ini. Kegiatan ini bertujuan untuk membantu masyarakat agar mampu melakukan budidaya ayam pedaging dengan persyaratan teknis produksi ayam yang baik, sehingga memberikan nilai ekonomis yang lebih tinggi dan selanjutnya akan mensejahterakan masyarakat setempat.

\section{METODE KEGIATAN}

\section{Pendekatan dan Metodologi}

Kegiatan dilaksanakan selama 3 bulan di Desa Haur Gading Kec. Batang Alai kab. HST Prov. Kalimantan Selatan. Metode kegiatan dilaksanakan terbagi ke dalam 2 tahapan yaitu sosialisasi program, dan pelaksanaan kegiatan. Realisasi program masingmasing tahapan disajikan di bawah ini.

Tahapan kegiatan yang dilaksanakan meliputi:

a. Kegiatan Padiatapa

Kegiatan Padiatapa dilaksanakan untuk mendapatkan persetujuan dari masyarakat dan aparat desa tempat lokasi kegiatan, agar kegiatan revitalisasi didukung dan dibantu kesuksesannya oleh masyarakat penerima paket revitalisasi.

b. Sosialisasi program kegiatan

Sosialisasi untul menyampaiakan program dan tahapan kegiatan yang akan dialksanakan bersama peserta kegiatan yaitu masyarakat desa Haur Gading kec. Batangalai Utara Kab. Hulu Sungai Tengah.

c. Pelaksanaan kegiatan:

1. Pelatihan teknis perkandangan untuk budidaya ayam pedaging 
2. Pelatihan bibit budidaya ayam pedaging

3. Pendampingan dalam pelaksanaan vaksin ayam pedaging (tetes mata)

4. Pendampingan dalam teknis strategi pemasaran ayam pedaging

d. Monitoring dan evaluasi kegiatan.

e. Pendampingan untuk keberlanjutan program.

\section{Khalayak Sasaran Sebagai Peserta} Kegiatan

Peserta kegiatan adalah Masyarakat yang ada di Desa Haur Gading Kecamatan Batangalai Utara (kelompok peternakan).

\section{Paket Program}

Kegiatan inti terdiri dari paket program dengan total Rp. 75.450.000,-

1) Peternak mendapat 1000 ekor bibit ayam (doc) dengan total biaya $\mathrm{Rp}$. 7.500 .000

2) Peternak mendapat pakan ayam untuk 1 periode panen sebanyak 70 sak @ 50 kg (350 kg) seharga Rp.28.000.000,-

3) Bantuan kandang ayam sebesar total biaya Rp. 30.000 .000

4) Bantuan obat dan vaksin sebesar total biaya Rp. 700.000
5) Bantuan peralatan kandang Rp. 9.250 .000

\section{Monitoring dan Evaluasi Kegiatan}

Evaluasi keberhasilan kegiatan dilakukan dengan beberapa indikator yang dibuat sebelum pelaksanaan kegiatan, disusun berdasarkan kriteria yang diperoleh pada saat survei awal kegiatan sebelum kegiatan

\section{HASIL KEGIATAN}

\section{Kegiatan Padiatapa}

Kegiatan

Padiatapa dilaksanakan di awal kegiatan bertujuan untuk mendapatkan persetujuan masyarakat tanpa paksaan melalui penjelasan tentang tujuan dan manfaat kegiatan ini serta kepastian informasi berkaitan dengan kegiatan teknis budidaya ternak unggulan utamanya ternak ayam pedaging, dimana informasi tersebut meliputi ada tidaknya peternak ayam pedaging, jumlah populasi ayam pedaging yang dipelihara, potensi pakan yang ada serta memetakan lokasi strategis untuk letak kandang ternak ayam pedaging yang akan dibuat berjumlah satu (1) unit kandang berkapasitas 1.000 ekor ayam pedaging. Kegiatan padiatapa dilakukan dengan menghadirkan kepala 
desa dan perangkat serta peserta kegiatan revitalisasi ayam pedaging yang berjumlah 25 orang. Setelah persetujuan dicapai berdasarkan kesepahaman bersama antara tim pelaksana kegiatan (tim revitalisasi) dan tim BRG dengan pihak desa maka dituangkan dalam formulir Padiatapa yang ditandatangani oleh seluruh peserta kegiatan yang berjumlah 25 orang, dan juga perangkat desa yaitu kepala desa, sekretaris desa dan tokoh masyarakat. Kesepakatan dalam formulir padiatapa tersebut sebagai bukti sahnya dan legalnya kegiatan yang akan dilaksanakan setelah penandatangan tersebut.
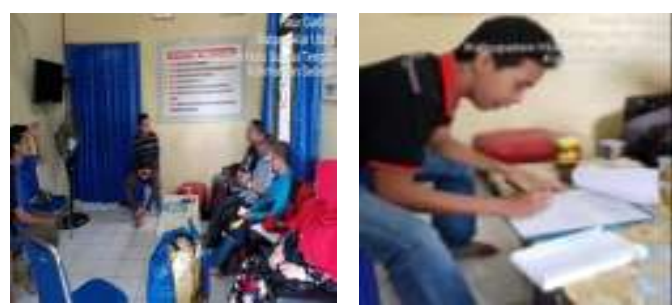

Gambar 1. Penandatanganan formulir Padiatapa di desa Haur Gading

\section{Sosialisasi Kegiatan}

Kegiatan sosialisasi dimulai penyampaian sambutan ketua tim pelaksana dan kades desa Haur Gading yang dihadiri perangkat desa lainnya dan peserta sosialisasi. Hasil kegiatan sosialisasi yang dilaksanakan adalah sebagai berikut :

a. Perangkat Desa (Kepala Desa, Sekdes dan masyarakat) mendukung kegiatan revitalisasi ayam pedaging yang di programkan tim dan akan mendukung dari awal hingga berakhirnya kegiatan .

b. Pada saat akhir kegiatan sosialisasi, tim pelaksana kegiatan revitalisasi juga mengadakan pertemuan dengan peserta kegiatan di desa Haur Gading yang bertanggung jawab untuk pembuatan kandang ayam pedaging . Tim pelaksana membawa sketsa dan spek kandang yang telah dibuat tim.

c. Disepakati beberapa revisi bahan kandang untuk mengefisienkan harga kandang dan memanfaatkan bahan lokal yang mudah dan tersedia di lokasi, dengan catatan tidak merubah sketsa kandang hanya spek bahan yang menyesuaikan.

d. Estimasi penyelesaikan kandang selama waktu 14 hari .

e. Harapan masyarakat kegiatan dapat berlanjut tahun depan agar pemeliharaan ayam pedaging sampai berhasil, dan keuntungannya dapat digunakan 
untuk mengembangkan ternak ayam dengan jumlah yang lebih besar sehingga lebih menjanjikan keuntungannya.
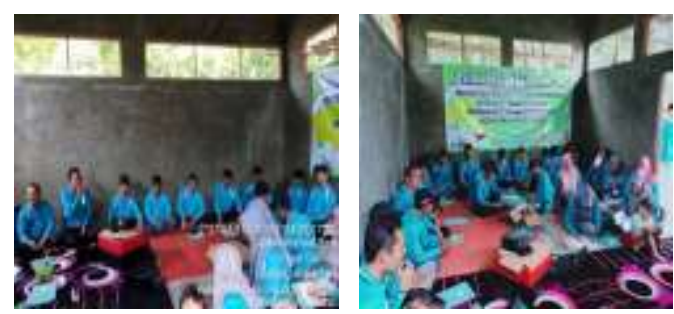

Gambar 2. Sosialisasi kegiatan bersama perangkat desa dan masyarakat

\section{Pembuatan kandang Ayam Broiler Sistem Panggung}

Pelatihan teknis pembauatn kandang dilaksanakan bertujuan untuk mempersiapkan kandang ayam pedaging mengikuti desain kandang sistem panggung model gable (dua sisi) dengan sisi setengah terbuka (open side wall), spek bahan, kapasitas dan ukuran kandang yang akan disepakati sesuai anggaran tim pelaksana dan kebutuhan masyarakat. Tim telah membuat sketsa dan desain kandang dan dibawa ke lokasi untuk didiskusikan bersama terkait rencana pembuatan 1 unit kandang ayam pedaging yang direncanakan bentuk Kandang Panggung agar aman dan tidak kena luapan air saat banjir atau air naik. Hal ini akan membantu kesehatan dan kontinuitas pemeliharaan ayam pedaging di masa datang yang terus menjamin kesejahteraan keluarga. Kandang yang dibuat digunakan untuk kapasitas 1.000 ekor ayam pedaging dengan kepadatan 8 ekor $/ \mathrm{m}^{2}$ sehingga luas kandang berkisar $125 \mathrm{~m}^{2}$. Dengan demikian ditetapkan lebar dan panjang kandang yang dibangun berukuran lebar $7 \mathrm{~m}$ dengan panjang $17 \mathrm{~m}$. Bahan dasar dari bilah bambu untuk alas dan dinding kandang ayam, seementara penyangga utama panggung kandang digunakan semua dari kayu ulin agar masa ekonomis kandang bisa mencapai 5-8 tahun dan hanya dilakukan sulam atap kandang dari rumbia setiap periode panen apabila diperlukan ada kebocoran. Jarak antar kisi atau bilah bambu di alas kandang sebesar $2 \mathrm{~cm}$ sementara jarak kisi antar bilah bambu dinding kandang sebesar 2,5 $\mathrm{cm}$. Kandang yang telah selesai mengacu desains kandangnya.

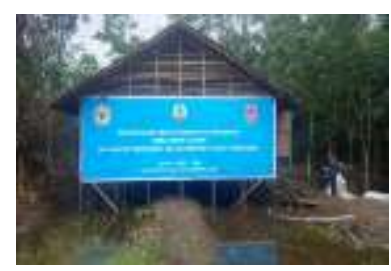

Gambar 3. Tampak muka kandang ayam broiler yang dibuat dengan ukuran 7 x 17 m berkapasitas 1000 ekor ayam pedaging 


\section{Pelatihan Teknis Budidaya Ayam \\ Pedaging}

Pelatihan teknis bertujuan untuk memberi keterampilan teknis dalam budidaya ayam pedaging mulai periode awal anak (starter 1-2 minggu) hingga periode finisher (3-4 minggu). Tahapan kegiatan mulai penyiapan anak ayam yang datang dengan pemberian air gula konsentrasi $3 \%$ di air minum, pemberiaan awal pakan, penyiapan tempat minum ayam dengan niple otomatis dan manual (tube waterer), pemasangan tempat pakan ayam otomatis (tube feeder), pemasangan dan penyalaan pemanas ayam berupa gas solek, penyiapan chick guard, litter sekam sebagai alas doc, pemasangan dan penutupan tirai kandang, serta upaya kesehatan yang harus dilakukan mulai dari program vaksinasi ND I, IBD (Gumboro), ND II serta pemberian vitamin dalam menjaga dan meningkatkan imunitas pada cuaca yang kurang baik.

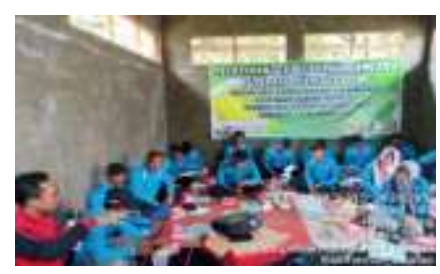

Gambar 4. Kegiatan pelatihan teknis budidaya ayam pedaging

\section{Pelaksanaan Kegiatan Budidaya} Ayam Pedaging

Kegiatan budidaya ayam pedaging dilaksanakan diawali dengan memasukkan anak ayam (doc) sebanyak 1000 ekor bibit ayam atau 10 boks ayam dengan isi 100 doc/boks dalam kandang ukuran $7 \times 17 \mathrm{~m}$ atau $120 \mathrm{~m}^{2}$, dengan kepadatan kandang $8 \mathrm{ekor} / \mathrm{m}^{2}$ sesuai rekomendasi North and Bell (2004) untuk daerah tropis. Hal ini didukung pernyataan Ruhyat (2006) dimana daya tampung kandang yang sesuai akan menjamin pertumbuhan dan kondisi ayam yang sehat dan berkembang baik di pertumbuhan awal (hiperplasi) dan pencapaian pertumbuhan akhir (hiperthropy). Bau dan amonia dari kotoran ayam juga akan mudah menguap dan tidak akan mengganggu kesehatan ayam di dalam kandang.
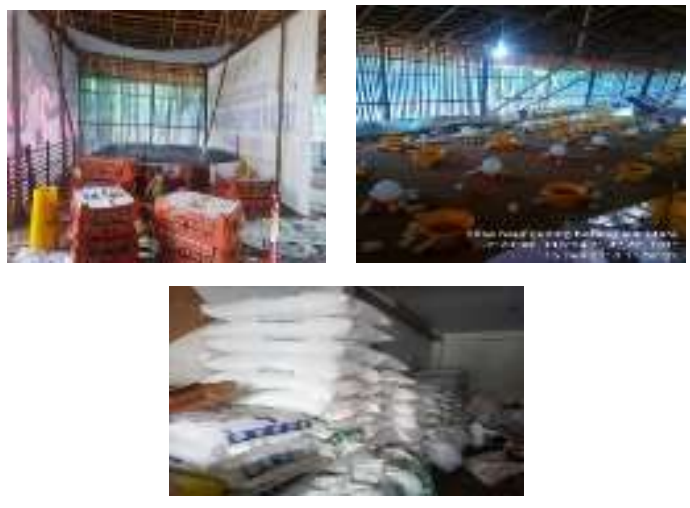

Gambar 5. Pembelian bibit ayam dan pakan serta kondisi anak ayam pedaging pada pemeliharaan umur 1 minggu 
Doc bibit anak ayam umur 1 hari yang didatangkan adalah "merk MB" diproduksi oleh PT Japfa Comfeed Indonesia dengan pertimbangan doc berkualitas baik yang akan menunjang perkembangan ayam yang baik dan sehat dengan bobot awal relatif homogen antara $40-42$ g/ekor. Sedangkan pakan yang digunakan adalah pakan jenis starter untuk umur 12 minggu awal sebanyak 35 sak (1.750 $\mathrm{kg}$ ), dan pakan finisher untuk umur 3-4 minggu hingga panen sebanyak 35 sak $(1.750 \mathrm{~kg})$, yang berasal dari perusahaan yang sama yaitu pakan "jenis BR 1 untuk starter" dan pakan "jenis BR 2 untuk finisher". Dengan asumsi bahwa settiap ekor ayam dari awal hingga akhir panen mengkonsumsi rata $150 \mathrm{~g} / \mathrm{ekor} / 31$ hari panen, dan estimasi FCR atau feed convertion ratio 1.6-1.8 maka prediksi saat panen akan dicapai dengan bobot $1,8-2,0$ kg/ekor dalam 30 hari pemeliharaan. Target dan capaian pertumbuhan ini sesuai yang digunakan bagi ayam pedaging yang berkembang di Indonesia yang hanya menggunakan 2 jenis pakan saja yaitu pakan strter dan finisher, berbeda dengan yang dikembangkan di daerah temperate (4 musim) di Eropa dan Amerika yang capaiannya saat panen lebih besar antara
3-3,5 kg/ekor dengan menggunakan 3 jenis pakan yang berbeda dari awal hingga akhir panen yaitu jenis pakan starter, pakan grower dan pakan finisher (Amrullah, 2004; North and Bell, 2004). Keterampilan teknis cara vaksinasi juga diberikan tim pelaksana meliputi pengenalan jenis vaksin, cara mencampur vaksin dengan pelarut, cara melakukan vaksin di mata secara tetes mata dan cara mengamankan dan membuang vaksin sisa vaksin secara aman agar tidak merugikan kesehatan ayam. Beberapa sample peserta kegiatan diundang dan dilatih khusus agar dapat melakukan vaksin nantinya secara mandiri. Biyatmoko dan Rostini (2009) menyatakan bahwa vaksin di ayam pedaging dilakukan pada tiga tahapan meliputi vaksin tahap 1 yaiutu vaksin ND I lewat tetes mata, diikuti vaksin tahap 2 yaitu vaksin IBD (Gumboro) diumur 12 hari dan terakhir tahap 3 yaitu vaksin ND II di umur 22 hari dari umur anak ayam. Vaksin yang dilakukan akan menjamin imunitas dan kekebalan ayam terhadap penyakit yang disebabkan oleh agen penyakit utamanya oleh virus (Ruhyat, 2006); North and Bell, 2004). Untuk itu pemeliharaan kebersihan dan sanitasi lingkungan sangat diperlukan untuk 
dapat mengeliminir penyakit yang potensial di kandang (Rasyaf, 1998).
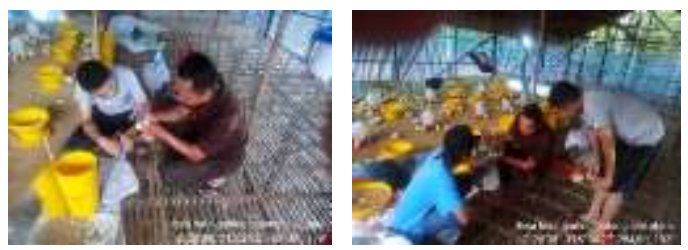

Gambar 6. Pelatihan vaksinasi pada ayam oleh tim dan peternak

\section{Pendampingan Teknis Pemasaran}

Kegiatan pendampingan pada peternak bertujuan untuk membantu menjual produk usahanya dari program revit yaitu ayam pedaging saat panen, terkait dimana menjualnya, kepada siapa menjualnya, gambaran harga jualnya , serta gambaran keuntungan. Kepada peserta juga diberikan berapa titik impas atau BEP (Break even point) harga dan BEP hasil produksi dari ayam yang dipelihara agar memudahkan bargaining terhadap broker ayam, sesuai arahan usaha beternak ayam secara agribisnis dalam Peraturan Pemerintah No 16 tahun 1977 dan Keputusan Presiden No. 22 Tahun 1990, SK Menteri Pertanian No. 62/Kpts/TN.120/1990 dan No.472/Kpts/TN.330/6/1996 dan SK Direktur Bina Pembibitan No. TN 270/346/C/III-0296, tentang pengaturan Pengembangan Budidaya Ayam ras
Pedaging. Dengan demikian peserta revit ayam pedaging tidak akan dirugikan dan bisa memperoleh margin yang layak. Nantinya mereka akan dapat mengembangkan usahanya lebih besar dari skala 1.000 ekor ayam pedaging yang saat ini mereka pelihara di kandang.

Lokasi kandang yang masih longgar lahannya dan agak jauh dari pemukiman akan menjadi pertimbangan untuk terus memperbesar skala usaha menjadi skala usaha yang lebih ekonomis pada skala usaha 2500 sampai 3000 ekor per kandang (Jaelani et al., 2008). Sehingga kandang yang saat ini luasnya kurang lebih $120 \mathrm{~m}^{2}$ masih memungkinkan diperbesar menjadi kisaran 250 sampai $300 \mathrm{~m}^{2}$ yang mampu menampung $2500 \quad-3000$ ayam pedaging di masa akan datang. Peningkatan kapasitas isi ayam dalam kandang ini akan memudahkan peserta untuk diikutkan dalam kemitraan dengan perusahaan pengembang ayam pedaging (Yana et al., 2006; Gittinger, 1986; PP No 44. Tahun, 1997). Berdasarkan statistik peternakan terdapat 13 nama perusahaan inti yang terlibat dalam kemitraan ayam pedaging dengan peternak dan tersebar di wilayah HSS. Perusahaan inti antara lain PT. 
Primarta Karya Persada (PKP), PT.

Ciomas Abadi Sentosa (CAS), PT.

Surya Intan Mandiri (SIM), dan PT.

Patriot Mandiri Unggas Jaya (PMUJ).

Sementara jumlah plasma yang terlibat sangat besar berkisar 462 KK aktif, sehingga akan sangat mudah untuk juga dikembangkan di Kab. HST khususnya di daerah Barabai dan desa Haur Gading. Profil pengusaha kemitraan selengkapnya disajikan pada tabel di bawah ini. Hal ini menjadi angin segar untuk keberlanjutan usaha yang saat ini tengah dirintis ini sebagai kegiatan revitalisasi ayam pedaging di desa Haur Gading, sehingga masa depan dan prospek masih terbuka lebar dan cerah bagi pengembangan keberlanjutan ayam pedaging di desa Haur Gading dan Barabai khususnya dan Kab. HST pada umumnya.

\section{KESIMPULAN}

Melalui kegiatan budidaya ayam pedaging ini masyarakat mempunyai keterampilan dan usaha sampingan serta memberikan keterampilan budidaya ayam pedaging dengan persyaratan teknis produksi ayam yang baik, menciptakan usaha peternak ayam pedaging skala kecil sampai meningkatkan usahanya ke agribisnis melalui intensifikasi usaha ternak dan menjadikan desa Haur Gading sebagai desa percontohan budidaya ayam pedaging di kawasan kec. Batangalai Utara Kab. HSS.

\section{DAFTAR PUSTAKA}

Amrullah, I.K. 2004. Nutrisi Ayam Pedaging. Edisi Ketiga. Lembaga Satu Gunungbudi, Bogor.

Anonim. 2007. Praktik Pendanaan Komoditas dengan Jaminan Resi Gudang. Kementrian Negara Koperasi dan Usaha Kecil dan Menengah Republik Indonesia. Jakarta.

Biyatmoko,D dan T. Rostini. 2009. Pola Pembiayaan Budidaya Ayam Ras Pedaging Di Kabupaten Banjar. Kelompok Pemberdayaan Sektor Riil dan UKM, Kantor Bank Indonesia Banjarmasin.

Buku Saku Peternakan Provinsi Kalimantan Selatan. 2019. Dinas Perkebunan dan Peternakan Provinsi Kalimantan Selatan.

Cahyono, Bambang. 1995. Cara Meningkatkan Budidaya Ayam Ras Pedaging (Broiler). Penerbit Pustaka Nusatama Yogyakarta

Card and Nesheim. Poultry Production. 1979. 12 $2^{\text {th }}$ Ed. Lea \& Febiger. Philadelphia.

Direktorat Bina Usaha Petani Ternak dan Pengolahan Hasil Ternak 1997. Usaha Peternakan, Perencanaan Usaha, Analisa dan Pengelolaan . Jakarta

Gittinger, Price. J. 1986. Economi Analysis of Agricultural Project. Terjemahan Universitas 
Indonesia (UI- Press). Edisi Kedua. Jakarta.

Jaelani, A. Rostini,T. Firahmi, N dan Prihatini, M,A. 2008. Potensi dan Permasalahan Pengembangan Ayam Ras Pedaging Melalui Pendekatan Klaster di Kabupaten Tanah Laut Kalimantan Selatan. Laporan Penelitian Uniska. Banjarmasin.

Keputusan Presiden No. 22 Tahun 1990, SK Menteri Pertanian No. 62/Kpts/TN.120/1990 dan No.472/Kpts/TN.330/6/1996 .SK Direktur Bina Pembibitan No. TN 270/346/C/III-0296, Tentang pengaturan Pengembangan Budidaya Ayam ras Pedaging

Kalimantan Dalam Angka. 2008. Badan Pusat Statistik Provinsi Kalimantan Selatan.

Laporan Analisa Supply \& Demand Daging dan Telur Kalimantan Selatan Tahun 2008 Sub Dinas Pengolahan dan Mutu Hasil Dinas Peternakan Provinsi Kalimantan Selatan, Banjarnaru.

Menteri Pertanian Republik Indonesia. 2002. Pedoman Perizinan dan Pendaftaran Usaha Peternakan. Jakarta.

Muhammad Rasyaf, 1998. Beternak Ayam Pedaging. Penerbit Penebar Swadaya Jakarta.
North, M.O and D.D. Bell. 1994. Commercial Chicken Production Manual. Published by Van Nostrand Reinhold, New York.

Produksi Peternakan Provinsi Kalimantan Selatan. 2008. Laporan Biro Perekonomian Sekretariat Daerah Provinsi Kalimantan Selatan. Banjarbaru.

Peraturan Pemerintah No 44. Tahun 1997 Tentang Kemitraan. Jakarta

Peraturan Pemerintah No 16 tahun 1977. Tentang Usaha Peternakan. Jakarta.

Ruhyat Kartasudjana dan Suprijatna, E.. 2006. Manajemen Ternak Unggas. PT. Penebar Swadaya. Jakarta Undang-undang No 9 . Tahun 1995 Tentang Usaha Kecil .

Rostini, T. Dan Biyatmoko D. 2020. Pemanfaatan limbah udang pada peternakan Itik Layer Guntung Manggis Kota Banjarbaru, Jurnal Al Ikhlas Vol 5 no 2. Pp 166-175.

Yana Supriyatna, Sri Wahyuni Dan I Wayan Rusastra. 2006. Analisis Kelembagaan Kemitraan Usaha Ternak Ayam Ras Pedaging,Laporan Seminar Nasional Teknologi Peternakan dan Veteriner . Jakarta. 